\title{
Prevalence of malnutrition among under-five children in Al-Nohoud province Western Kordufan, Sudan
}

\author{
Elmanssury A. Elnadif \\ Department of Public Health, College of Public Health and Health Informatics, Qassim University, Al Bukairiyah, \\ Saudi Arabia
}

\begin{tabular}{l} 
Article Info \\
\hline Article history: \\
Received Jun 15, 2020 \\
Revised Aug 26, 2020 \\
Accepted Sep 11, 2020 \\
\hline
\end{tabular}

\section{Keywords:}

Malnutrition

Prevalence

Stunting

Under-five children

Underweight

\begin{abstract}
Malnutrition remains one of the most common causes of childhood morbidity and mortality worldwide. The objective of this research was to determine the prevalence of malnutrition and related factors among Al-Nohoud children between 6-59 months of age. For the choice of parts, blocks and households, a three-stage sample design was used. Data collection was focused on anthropometric tests and structured questionnaires. The prevailing low weight, stunting and wasting of $16.7 \%, 13.5 \%$ and $17.6 \%$, respectively, was shown. Two thirds (67\%) \%) of the affected children were 24 months. Female children were further underweight than male children. Home-wives achieved lower education levels and were higher in the mothers of malnourished children than those with healthy children. This study found that age of mothers, mother and family income have substantial malnutrition linked to children under the age of five $(p=000, X 2=57.40)(p=.004$, $\mathrm{X} 2=41.00)(\mathrm{p}=.00, \mathrm{X} 2=32.74)$. The study found that under-five children were particularly malnutrition. Age ranges were significantly linked to wasting, stunting and underweight. Sex, mother's age, mother's level of education and family income differ greatly from malnutrition for children under the age of five.
\end{abstract}

This is an open access article under the CC BY-SA license.

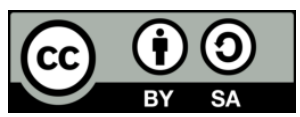

\section{Corresponding Author:}

Elmanssury A. Elnadif,

Department of Public Health, College of Public Health and Health Informatics,

Qassim University,

Al-Bukayriyah, Saudi Arabia.

Email: elnadif269@yahoo.com

\section{INTRODUCTION}

Malnutrition is a main health problem, particularly in unindustrialized countries. It affects nearly 800 million people- $20 \%$ of all in the emergent world. It is related with around half of all child deaths worldwide [1]. Successful nutrition is important for balanced childhood growth and development. Malnutrition refers to a pathological condition resulting from a relative or absolute or extra deficiency of one or more essential nutrients [2]. Wasting, stumping and underweight are anthropometric indicators frequently used in the population of less than five children to measure under nutrition [3]. Wastage, beautiful and underground weight are referred to by the World Health Organization (WHO) as z-scores lower than -2 normal weight disparities in height, height for age and weight for age. [4]. The forest and stunting of nutrient deficits represent acute and chronic effects. Furthermore, low weight shows both acute and chronic nutrient deficiency findings [5,6]. Child malnutrition figures identify the severity and trends of undernutrition, overweight, and obesity of stunting, wasting, and underweight. The inter-agency community reports also update global and national statistics in terms of the prevalence and the numbers for each measure. UNICEF-WHO-WB Joint Child Malnutrition Reports. 
In 2019, internationally 144 million children under the age of 5 years of age were stunted, 47 million wasted,38 million overweight [7]. Malnourished children are more likely to be decreased resistance to infection, to die of common infantile diseases such as diarrheal diseases and respiratory infections; and frequent disease saps their nutritional condition for those living, putting them in a rough cycle, which leads to uncertain growth and decreased ability to learn [1]. Child malnutrition, particularly in developing countries, is one of the most important causes of disease and death in the world [8]. It is the main risk factor for disease incidence, causing approximately 300,000 deaths a year, and is responsible for more than half of all deaths in children directly or indirectly [9]. About 60 million and 13 million children worldwide suffer correspondingly from mild to serious acute malnutrition [10]. The world study reveals that the age levels of outstanding, underweight and waste are $21.9 \%, 13.4 \%$, and $7.3 \%$ of the population group under-five [11]. In Sub-Saharan Africa, like Ethiopia, the WHO have reported about 5.4 million young children per year die with 2.7 million deaths [12].

Most studies note the physical and health importance of infant malnutrition, such as physical growth and motor development, lower intelligence quotients, greater behavioral challenges, lack of social competencies, and disease susceptibility. Child malnutrition can lead to higher phases of chronic diseases in adulthood, as malnourished females are more likely to give birth to low-weight babies [13, 14]. Malnutrition isn't a single, simple solution problem. The cause of malnutrition involves multiple and hierarchically interrelated determinants [15]. The main problems are insufficient dietary and illness caused by a number of basic factors themselves: insecurity of the household foodstuffs, poor mother/child care and poor access to basic health services, including the absence of safe water and unhealthy living conditions, such as open defecation $[16,17]$. In addition, these underpinning causes themselves are influered by the economic, political, and socio-cultural conditions of children under-five in the West-Kordufan province of Al-nuhud; their abilities, wealth, the environmental conditions and governance [18].

\section{RESEARCH METHOD}

\subsection{Study design and sampling}

This community based descriptive Cross-sectional study, has been done in Al-Nohoud locality, Sudan. The study populations are children under-five years in Al-Nohoud town and their mother. The inclusion criteria were all ages of children below five years and their mothers in study area. And exclusion criteria were all ages of children above five years and their mothers in study area. The sample size was determined for study area using the formula for cluster surveys. It was calculated on the basis of prevalence of $50 \%$ and design effect of 1.5. Sample size was 384. As a multistage sampling technique was working to identify study subjects, a design effect of 2 was used; thus, the final sample size was 768. The multistage cluster-sampling technique was followed for selecting the study population.

\subsection{Data collection}

Questionnaire was used for collecting data. Public health officers and immunization technicians were trained on questionnaire to be used to collect data from the households. In accordance with the methods of nutrition guidelines, anthropometric measurements of selected child (mid-upper brain diameter-MUAC, weight and length/height) were taken. For children without control, the body weight had been determined by means of a hanging baby scale of $15 \mathrm{~g}$ (mechanical hanging baby scale of up to $15 \mathrm{~kg}$ or $25 \mathrm{~kg}$ SECA310). A mechanical dial weighing scale, manufactured in Japan, has been used for elderly children with a capacity of $130 \mathrm{~kg}$. For light clothes, without shoes, both children were measured for $0.1 \mathrm{~kg}$ as similar as possible; measurements were double-checked. Before and after the survey was started, the scales were checked for exactness and then periodically reviewed.

Carefully calibrated height/ lengths are doing by using an inelastic tape of the nearest $0.1 \mathrm{~cm}$. The standing measurements were used to measure children over 24 months of age (height over or equal to $85 \mathrm{~cm}$ ), who lying below 24 months of age, or less than $85 \mathrm{~cm}$. Mid-upper arm circumference (MUAC) was measured using children in centimeters, and reported to approximately $0.1 \mathrm{~cm}$. At the middle point between the elbow and shoulder the calculation was performed in the left arm, while the arm was relaxed. In order to test severe protein-energy malnutrition (PEM), which is one of the signs of kwashiorkor; clinical examinations of children who have been malnourished were undertaken.

\subsection{Statistical analysis}

After the data collection, the data was implied and conveyed into particularly designed formats to be appropriate for computer feeding. An analysis of correlation (Chi square) was used to find the significance of study parameters between two or more group of samples. The Social Science Statistical System was used for review (SPSS version 22).

Prevalence of malnutrition among under-five children in Al-Nohoud province... (Elmanssury, A. Elnadif) 


\subsection{Ethical considerations}

The proposal was submitted to the post graduate board of the faculty of public health for approval. The consent letters for conducting this research was obtained from the concerned health authority (head quarter of general administration for health and population). At the initial interview, each potential subject was informed about the nature, purpose and benefits of the study, and informs that his/her participation is voluntary. The respondents were assured that the collected data and information was confidential and used only for study purpose and the findings of the research may contribute to policies that help to improve implementation of health programs in the town.

\section{RESULTS AND DISCUSTION}

\subsection{Results}

Figure 1 shows malnutrition prevalence among children below the age of five. The figure clearly reveals that $17.6 \%$ of children were wasted $\left(\mathrm{WHZ}<\_2\right.$ ), $13.5 \%$ were stunted (HAZ <_2), and $16.7 \%$ were underweight (WAZ <_2). Malnutrition was reported mainly among children with 2 years' age, and of this category $19.1 \%$ were stunted $\left(\mathrm{HAZ}<\_2\right.$ ), $26.2 \%$ were wasting $($ WHZ < _2), and $21.8 \%$ were underweight (WAZ < _2). Table 1 shows the data stratified by age and severity. Prevalence of wasting was similar between children in the age of 3 and 5 years respectively. It is shown that wasting, stunting, and underweight are significantly associated with age group $(\mathrm{p}-\mathrm{v}=, 000)$. Childhood malnutrition prevalence could vary between males and females due to unequal access to food and health resources. However, differences between sex was highly statistical significant for stunting, wasting/thinness and underweight (p-value $<.000)$ as shown in Table 2.

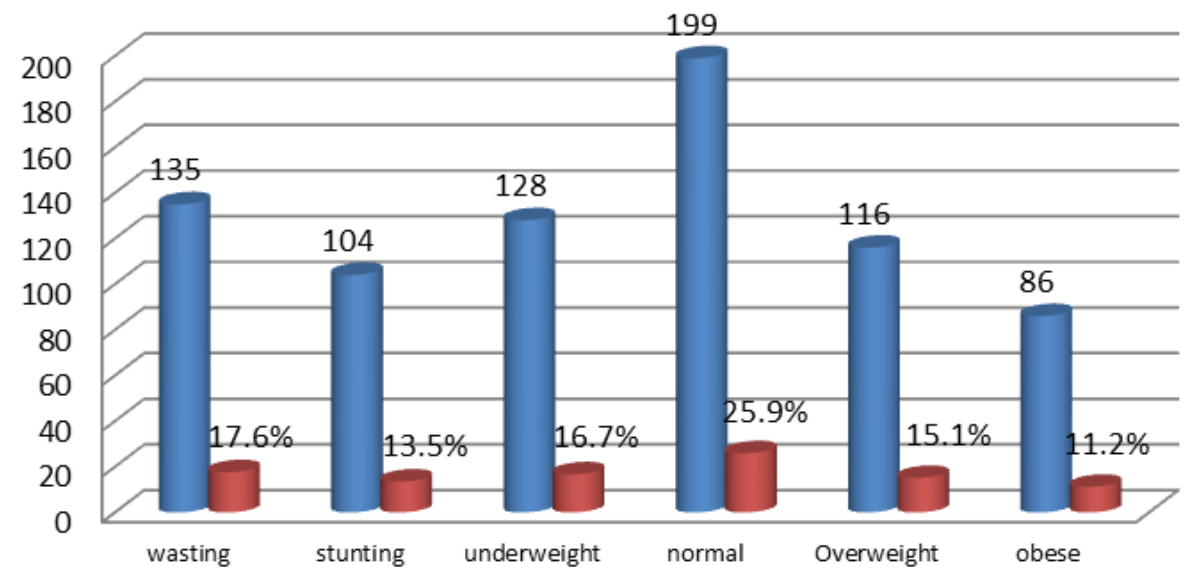

Figure 1. Malnutrition prevalence among children

Table. Prevalence of malnutrition among children based on age

\begin{tabular}{|c|c|c|c|c|c|c|c|}
\hline \multirow{2}{*}{$\begin{array}{c}\text { Malnutrition } \\
\text { category }\end{array}$} & \multicolumn{7}{|c|}{ Age groups } \\
\hline & $\begin{array}{c}1 \text { year } \\
\text { No }(\%)\end{array}$ & $\begin{array}{l}2 \text { years } \\
\text { No }(\%)\end{array}$ & $\begin{array}{c}\text { 3years } \\
\text { No }(\%)\end{array}$ & $\begin{array}{l}\text { 4years } \\
\text { No }(\%)\end{array}$ & $\begin{array}{c}\text { 5years } \\
\text { No }(\%)\end{array}$ & $\begin{array}{c}\text { Total } \\
\text { No }(\%)\end{array}$ & $\mathrm{p}-\mathrm{v}$ \\
\hline Wasting & $22(6,0)$ & $96(26.2)$ & $7(1.9)$ & $3(0.8)$ & $7(1.9)$ & $135(36.8)$ & \\
\hline Stunting & $10(2.7)$ & $70(19.1)$ & $16(4.4)$ & $2(0.5)$ & $6(1.6)$ & $104(28.3)$ & \\
\hline Underweight & $27(7.4)$ & $80(21.8)$ & $17(4.6)$ & $1(0.3)$ & $3(0.9)$ & $128(38.9)$ & .000 \\
\hline Total & $59(16.1)$ & $246(67.1)$ & $40(10.8)$ & $6(1.6)$ & $16(4.4)$ & $367(100)$ & \\
\hline
\end{tabular}

Table 2. Prevalence of malnutrition among children based on gender

\begin{tabular}{ccccc}
\hline Malnutrition & Male & Female & Tox & \\
category & No $(\%)$ & No $(\%)$ & No $(\%)$ & p-v \\
\hline Wasting & $64(17.4)$ & $71(19.3)$ & $135(36.8)$ & \\
Stunting & $47(12.8)$ & $57(15.5)$ & $104(28.3)$ & .000 \\
Underweight & $63(17.2)$ & $65(17.7)$ & $128(38.9)$ & \\
Total & $174(47.4)$ & $193(56.6)$ & $367(100)$ & \\
\hline
\end{tabular}


Table 3 shows the important association between the age of a baby, mother's education, and family income with infant malnutrition under 5 years, $(\mathrm{p}=.000, \mathrm{X} 2=57.40)(\mathrm{p}=.004, \mathrm{X} 2=41.00)$ $(\mathrm{p}=.000, \mathrm{X} 2=32.74)$. Sons of mothers $26-30$ years old have been less likely (underweight, waste and stunning) to become malnourished 66(8.6), 63(8.2), 55(7.5) respectively. With respect to schooling for mothers, the study shows that mothers from the elementary and secondary schools are more likely than mothers with higher education rates to experience malnutrition 133(17.3). Furthermore, the study found that family poverty (as of 2000) was 200(26.0) more likely than higher-income families to become malnourished.

Table 3. Factors linked to malnutrition among children

\begin{tabular}{|c|c|c|c|c|c|c|c|}
\hline \multirow[b]{2}{*}{$\begin{array}{l}\text { Demographic } \\
\text { characters }\end{array}$} & \multirow[b]{2}{*}{ Category } & \multicolumn{6}{|c|}{ Malnutrition category } \\
\hline & & $\begin{array}{l}\text { Wasting } \\
\text { No }(\%)\end{array}$ & $\begin{array}{l}\text { Stunting } \\
\text { No }(\%)\end{array}$ & $\begin{array}{l}\text { Underweight } \\
\text { No }(\%)\end{array}$ & $\begin{array}{c}\text { Total } \\
\text { No }(\%)\end{array}$ & $X^{2}$ & $\mathrm{p}-\mathrm{v}$ \\
\hline \multirow{7}{*}{ Age of mothers } & $\leq 25$ & $40(5.2)$ & $31(4.0)$ & $38(4.9)$ & $109(14.2)$ & \multirow{6}{*}{57.40} & \multirow{4}{*}{.000} \\
\hline & $26-30$ years & $63(8.2)$ & $55(7.5)$ & $66(8.6)$ & $184(24.0)$ & & \\
\hline & $31-35$ years & $12(1.6)$ & $7(0.9)$ & $11(1.4)$ & $30(3.9)$ & & \\
\hline & $\geq 36$ & $20(2.6)$ & $11(1.4)$ & $13(1.7)$ & $44(5.7)$ & & \\
\hline & Total & $135(17.6)$ & $104(13.5)$ & $128(16.7)$ & $367(47.8)$ & & \multirow{8}{*}{.004} \\
\hline & Illiterate & $22(2.9)$ & $14(1.8)$ & $15(2.0)$ & $51(6.6)$ & & \\
\hline & Primary school & $40(5.2)$ & $34(4.4)$ & $36(4.7)$ & $110(14.3)$ & \multirow{6}{*}{41.00} & \\
\hline \multirow{3}{*}{$\begin{array}{l}\text { Education of } \\
\text { mothers }\end{array}$} & $\begin{array}{c}\text { Secondary and high } \\
\text { school }\end{array}$ & $46(6.0)$ & $38(4.9)$ & $49(6.4)$ & $133(17.3)$ & & \\
\hline & University & $26(3.4)$ & $10(1.3)$ & $21(2.7)$ & $57(7.4)$ & & \\
\hline & Post graduate & $1(.2)$ & $8(1.0)$ & $7(0.9)$ & $16(2.1)$ & & \\
\hline \multirow{5}{*}{$\begin{array}{l}\text { Family income } \\
\text { size }\end{array}$} & Total & $135(17.6)$ & $104(13.5)$ & $128(16.7)$ & $367(47.8)$ & & \\
\hline & $\leq 2000$ & $72(9.4)$ & $57(7.4)$ & $71(9.2)$ & $200(26.0)$ & & \\
\hline & $2001-5000 \mathrm{SP}$ & $50(6.5)$ & $39(5.1)$ & $51(6.6)$ & $140(18.2)$ & \multirow{3}{*}{32.74} & \multirow{3}{*}{.000} \\
\hline & $>5010 \mathrm{SP}$ & $13(1.7)$ & $8(1.0)$ & $6(0.8)$ & $27(3.5)$ & & \\
\hline & Total & $135(17.6)$ & $104(13.5)$ & $128(16.7)$ & $367(47.8)$ & & \\
\hline
\end{tabular}

\subsection{Discussion}

In this study, the proportion of children under the age of five, who were $13.5 \%$ and $17.6 \%$, was shown to be less weight, stunning and wasting. Two thirds (67 percent) of affected children were 24 months of age with respect to the age of children in the study. Women were more likely than male children to be underweight. Through this research it has been noted that mothers, and families, are substantially related through age to education and in terms of malnutrition $\left(p=.000, X^{2}=57.40\right)\left(p=0.004, X^{2}=41.00\right)$ among children under the age of five $\left(\mathrm{p}=.000, \mathrm{X}^{2}=32.74\right)$. Mother's age group $(26-30$ years) were more likely to affect malnutrition (underweight, wasting and stunting respectively, 66(8.6), 63(8.2) 55(7.5). Regarding mother's education, study observed that secondary and high school were more likely to affect malnutrition 133(17.3) than other educational levels. And study also observed that family income $(\leq 2000)$ were more affects to malnutrition 200(26.0) than households in others income group.

The findings showed that 16.1 percent, 15.3 percent and 14.8 percent, of which were underweight and stunted, respectively are close to Rollt's malnutrition prevalence analysis for children of under-five and school-age children in the Milot Valley, Haiti [19]. However, the prevalence of underweight reported by Abera et al, Orji MC et al and Tekile et al was much higher (27.6\%), (24.5\%), (23.3\%), respectively than the present study [20-22]. The study of Hawassa Zuria showed that the underweight was greater than that of the Mai-Aini Eritreans, whereby 33.4 percent of children, and 24.6 percent of children, respectively, were underweight and wasteful, respectively, wasted by 31.9 percent and 23.6 percent respectively [23]. The differences in the findings might be due to the fact that later study was conducted among refugee camp, children covered in the study were dependent on humanitarian aid for food and nutrition [24]. Earlier studies [25, 26], reported similar findings regarding the age of children.

It is evident from the report that children younger than two years are among the most affected age groups because of a variety of reasons, including the low levels of exclusive breastfeeding as seen in this research. Wasting, stunting, and underweight among children were found to be significantly associated with age group $(\mathrm{p}-\mathrm{v}=.000)$. As shown by the study of Asfaw, et al and Hui Jie Wong et al [27, 28]. Nevertheless, this result is not consistent with a study in Bule Hora, Oromia District and Dollop Ado District Pastoral Group, Somalia, which stated that male children are more likely than females to be underweight [29, 30]. The higher proportion of the mothers of the malnourished children were housewives, less educational, less weighty and did not possess any personal property, as opposed to those of healthy children. 


\section{CONCLUSION}

The malnutrition of children aged 6-59 months in Al-Nohoud remains a serious problem for public health. This research indicates the severity of malnutrition in Al-Nohoud area. There was a high prevalence of malnutrition (underweight $16.7 \%$ and waste $17.6 \%$ ), which suggests that nutrition is very important in the study region. The malnutrition of children under the age of five years is significantly related to age, sex, children's health, mother, education level and family income. Waste-related factors include mother schooling and diarrhea prevalence.

\section{ACKNOWLEDGEMENTS}

For their cooperation during data collection, the authors would like to thank the data collectors. Congratulations are also due to the participants in the research.

\section{REFERENCES}

[1] Anon, ymous, "Nutritional status and risk factors of chronic malnutrition in children under five years of age in Aydin, a western city of Turkey," The Turkish Journal of Pediatrics, Vol. 49, No. 3, pp. 283-289, 2007.

[2] Mercedes de Onis, Majid Ezzati, Colin Mathers, "Maternal and Child Undernutrition 1: Maternal and child undernutrition: global and regional exposures and health consequences," The Lancet (British Edition), vol. 371, no. 9608 , pp. 243, 2008.

[3] M., P.V., and S.V, P., "Malnutrition and its related factors among children 0-5 years in rural Shamirpet mandal, Ranga reddy district, India,” International Journal of Bioassays, vol. 6, no. 4, pp. 5340, 2017.

[4] Zemenu Yohannes Kassa, Tsigereda Behailu, Alemu Mekonnen, Mesfine Teshome, Sintayehu Yeshitila, "Malnutrition and associated factors among under five children (6-59 Months) At Shashemene Referral Hospital, West Arsi Zone, Oromia, Ethiopia". Current Pediatric Research, vol. 21, no. 1, pp. 172-180, 2017.

[5] World Health Organization, and UNICEF, "WHO child growth standards and the identification of severe acute malnutrition in infants and children: joint statement by the World Health Organization and the United Nations Children's Fund," 2009

[6] Oestergaard, M.Z., Inoue, M., Yoshida, S., "Neonatal Mortality Levels for 193 Countries in 2009 with Trends since 1990: A Systematic Analysis of Progress, Projections, and Priorities,” PLoS Medicine, vol. 8, no. 8, pp. 1-13, 2011.

[7] World Health Organization, Global Health Observatory (GHO) data. [Online]. Available: https://www.who.int/gho/child-malnutrition/en/

[8] Janevic, T., Petrovic, O., Bjelic, I., "Risk factors for childhood malnutrition in Roma settlements in Serbia," BMC Public Health, vol. 10, no. 1, pp. 509, 2010.

[9] Amsalu, S. and Tigabu, T., "Risk factors for severe acute malnutrition in children under the age of five: a casecontrol study," Ethiopian Journal of Health Development, vol. 22, no. 1, pp. 21-25, 2008.

[10] Mekonnen, A., Jones, N., and Tefera, B., "Tackling child malnutrition in Ethiopia: do the sustainable development poverty reduction programme's underlying policy assumptions reflect local realities?," Young lives, London, GB, 2005.

[11] Islam, M.M., Alam, M., Tariquzaman, M., "Predictors of the number of under-five malnourished children in Bangladesh: application of the generalized poisson regression model," BMC Public Health, vol. 13, no. 1, pp. 11, 2013.

[12] Anonymous, "World: Nearly 385 million children living in extreme poverty, says joint World Bank GroupUNICEF study," Asia News Monitor, 2016.

[13] Anonymous "Levels and Trends in Child Mortality: Report 2012," Estimates Developed by the UN Inter-agency Group for Child Mortality Estimation; 2013 IIS 4020-S22, 2013.

[14] Kassahun Alemu, K.M., "Prevalence of Malnutrition and Associated Factors Among Children Aged 6-59 Months at Hidabu Abote District, North Shewa, Oromia Regional State," Journal of Nutritional Disorders \& Therapy, vol. 3, no. 3, pp. 1-15, 2013.

[15] Darsene, H., Geleto, A., Gebeyehu, A., "Magnitude and predictors of under nutrition among children aged six to fifty nine months in Ethiopia: a cross sectional study," Archives of Public Health= Archives Belges De Santé Publique, vol. 75, no. 1, pp. 29, 2017.

[16] Belaynew W, B.G., "Assessment of Factors Associated with Malnutrition among Under Five Years Age Children at Machakel Woreda, Northwest Ethiopia: A Case Control Study," Journal of Nutrition \& Food Sciences, vol. 4, no. 1 , pp. 1-7, 2014.

[17] Berhanu, G., Mekonnen, S., and Sisay, M., "Prevalence of stunting and associated factors among preschool children: A community based comparative cross sectional study in Ethiopia," BMC Nutrition, vol. 4, pp. 28, pp. 1-15, 2018.

[18] Abera, L., Dejene, T., and Laelago, T., "Prevalence of malnutrition and associated factors in children aged 6-59 months among rural dwellers of damot gale district, south Ethiopia: community based cross sectional study," International Journal for Equity in Health, vol. 16, no. 1, pp. 111, 2017.

[19] W, T., and B, T., "Prevalence of Acute Malnutrition (Wasting) and Associated Factors among Preschool Children Aged 36-60 Months at Hawassa Zuria, South Ethiopia: A Community Based Cross Sectional Study," Journal of Nutrition \& Food Sciences, vol. 6, no. 2, pp. 1-7, 2016.

[20] Rollet, S.R., Gray, E.S., Previl, H., "Prevalence of malnutrition in children under five and school-age children in Milot Valley, Haiti," Public Health, vol. 128, no. 12, pp. 1094-1098, 2014. 
[21] Orji MC, Onyire NB, Ojukwu JO, Obu CD., "Prevalence and predictors of undernutrition in HIV infected children on antiretroviral therapy in Abakaliki, Southeast Nigeria," International Journal Medical Sciences Public Health, vol. 9, no. 1, pp. 101-105, 2020.

[22] Tekile Abay Kassa, Woya Ashenafi Abate and Basha Garoma Wakjira, "Prevalence of malnutrition and associated factors among under-five children in Ethiopia: evidence from the 2016 Ethiopia Demographic and Health Survey," BMC Research Notes, vol. 12, no. 1, pp. 1-6, 2019.

[23] Dereje Danbe Debeko, Ayele Taye Goshu. "Nutritional Status of under-five Children in Hawassa Zuria District, Southern Ethiopia," American Journal of Health Research, vol. 3, no. 5, pp. 286-292, 2015.

[24] Bezatu Mengiste, H.K., "Prevalence of Acute Malnutrition and its Associated Factors among Children aged 6-59 months in Mai-Aini Eritrean Refugees' Camp, Northern Ethiopia," Journal of Nutrition \& Food Sciences, vol. 5, no. 1 , pp. 1-7, 2014.

[25] Kanan, S.O.H., and Swar, M.O., "Prevalence and outcome of severe malnutrition in children less than five-year-old in Omdurman Paediatric Hospital, Sudan," Sudanese Journal of Paediatrics, vol. 16, no. 1, pp. 23-30, 2016.

[26] Gernaat, H.B., Dechering, W.H., and Voorhoeve, H.W., "Mortality in severe protein-energy malnutrition at Nchelenge, Zambia," Journal of Tropical Pediatrics (1980), vol. 44, no. 4, pp. 211-217, 1998.

[27] Nnakwe N., "The effect and causes of protein-energy malnutrition in Nigerian children," Nutrition Research, vol. 15 , no. 6 , pp. 785-794. 1995 .

[28] Wong, H.J., Moy, F.M., and Nair, S., "Risk factors of malnutrition among preschool children in Terengganu, Malaysia: a case control study," BMC Public Health, vol. 14, no. 1, pp. 785, 2014.

[29] Asfaw, M., Wondaferash, M., Taha, M., "Prevalence of under nutrition and associated factors among children aged between six to fifty nine months in Bule Hora district, South Ethiopia," BMC Public Health, vol. 15, no. 1, pp. 41. 2015.

[30] Demissie S., "Magnitude and Factors Associated with Malnutrition in Children 6-59 Months of Age in Pastoral Community of Dollo Ado District, Somali Region, Ethiopia," Science Journal of Public Health, vol. 1, no. 4, pp. 175, 2013. 